\title{
RELIGIOUS PERIODICALS IN ENGLAND DURING THE RESTORATION AND EIGHTEENTH CENTURY
}

\author{
BY SAMUEL J. ROGAL
}

Dr. Rogal is an associate professor of English in State University College,

Oswego, New York. Rutgers Library houses printed material of the nature discussed

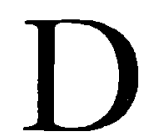

URING the Restoration and early eighteenth century, publishers of newspapers in England directed their efforts to collecting and circulating current news-especially matters of military concern. Discussions of a political nature occurred in pamphlets, broadsides, or periodical papers limited to that purpose. Thus the major essayists during the reign of Anne (I 702-I 7 I4)Defoe, Addison, Steele, Swift-concerned themselves with party differences, and the periodicals which they initiated and to which they contributed were never intended to fulfill the functions of regular news-sheets. The same held true during the greater portion of the Hanoverian period. For example, a journal entitled Cato's Letters appeared at the time of the South Sea Company collapse (I72I); Viscount Bolingbroke and William Pulteney found the Craftsman to be a convenient vehicle for attacking the ministry of Sir Robert Walpole (I72I-I742); and The North Briton of John Wilkes, which ran for seventy-eight numbers between 5 June 1762 and 31 December I 763 , existed as the major opposition voice at the beginning of the reign of George III.

However, by the I 770's, the overall character of British journalism evidenced decided changes. The development of newspapers and magazines either eliminated or merged with the volumes devoted solely to political and popular essays. For instance, Samuel Johnson's Rambler ( 208 numbers between 20 March 1750 and I4 March I 752) and John Hawkesworth's Adventurer (I752-I754)-to which Johnson and Joseph Warton were major contributors-were published separately, in the same manner as the Tatler and Spectator papers before them. Yet Johnson's Idler essays appeared every Saturday in The Universal Chronicle, or Weekly Gazette between 
I 5 April I758 and 5 April I760. Also, Oliver Goldsmith's The Citizen of the World came upon the scene first as "Chinese Letters" in The Public Ledger (a London daily newspaper published by John Newbery) between 24 January 1760 and I4 August I761. The essays were not published under their more recognizable title until I762.

Religious periodicals in England followed a somewhat different development during this period. Between the Popish Plot of Titus Oates in 1678 and the death of Charles II in I685, when Protestant extremists led by Anthony Ashley Cooper, First Earl of Shaftesbury, agitated strongly against Catholics in general and James, Duke of York, in particular, quasi-religious news-sheets appeared, mostly in support of Shaftesbury's proposed Exclusion Bill to prevent the succession of the King's Catholic brother to the throne. Thus, such sheets as The Weekly Visions of the Late Popish Plot (168I), The Protestant Oxford Intelligence (168I), and The Loyal Protestant and True Domestick Intelligence (168I-1683) proved to be more political than religious. However, throughout the reigns of Charles II, James II, and William and Mary, religion and politics were not easily separated or even clearly distinguished. Simply, one must draw a distinction between the religious-political news-sheets of the late seventeenth century and the theological journals and miscellanies that came into existence around the middle of the eighteenth century and began to flourish in the I770's and 1780's. Typical of this latter category is The Arminian Magazine of John Wesley.

The Arminian Magazine made its first appearance in January I 778, although Wesley had been collecting material for a journal since $\mathrm{I} 776$. His purpose was twofold: first, to supply his followers, persons not overly fond of reading or learning in general, with a practical and entertaining miscellany; second, to maintain and defend those of his doctrines that had been under attack from opponents contributing to such Calvinistic organs as The Gospel Magazine (I766-I773), Augustus M. Toplady's Gospel Magazine (r774-1784), The Library (1761-I762), and The Theological Repository ( I 766-I 770). In the preface to the first volume of The Arminian Magazine, Wesley complained that these journals

... are intended to show, that God is not loving to every man; that His mercy is not over all His works; and, consequently, that Christ did not die for us all, but for one in ten, for the elect only. This comfortable doc- 
trine, the sum of which, proposed in plain English, is, God, before the foundation of the world, absolutely and irrevocably decreed, that "some men shall be saved, do what they will, and the rest damned, do what they can," has, by these tracts, been spread throughout the land with the utmost dilligence. And these champions of it have, from the beginning, proceeded in a manner worthy of their cause. They have paid no more regard to goodnature, decency, or good manners, than to reason or truth: all these they set utterly at defiance. Without any deviation from their plan, they have defended their dear decrees, with arguments worthy of Bedlam, and with language worthy of Billingsgate. (Robert Southey, The Life of John Wesley and the Rise and Progress of Methodism [London: George Bell and Sons, I 901 ], p. 502.)

Considering John Wesley's bias, this is not too far from an accurate summary of theological journalism during the latter half of the eighteenth century. By I 74I, with the publication of The Weekly History - a Methodist newspaper founded by those who had seceded from Wesley's society-there was little resemblance between the Protestant news-sheets of the late seventeenth century and their doctrinal successors.

No checklist of religious news-sheets and journals for the Restoration and eighteenth century can be termed complete, owing to the obstacles confronting researchers in this particular area. A considerable number of periodicals has been lost through neglect and a general lack of interest on the part of contemporaries to preserve or collect issues. Also, the various taxations placed on periodicals during the eighteenth century contributed indirectly, though significantly, to further obstacles; simply, philatelists have been so eager to collect the tax stamps affixed to news-sheets or journals that they have destroyed or mutilated important evidence to the history of periodical literature. However, three catalogue sources-two primary and one secondary-do exist for the benefit of researchers and bibliographers. The British Museum houses the George Tomason Collection of newsbooks and pamphlet literature published between I64I and I660; also in the Museum is the Charles Burney Collection, which covers the period from 1620 to 1817 . In 1920 the Times (London) Publishing Company Limited issued a Tercentenary Handlist of English and Welsh Newspapers, Magazines and Reviews (reprinted London: Dawsons of Pall Mall, 1966), compiled from the major library collections. In addition to these, two volumes reprinted in 1968 by The Bibliographical Society are most 
helpful: Henry R. Plomer's A Dictionary of the Printers and Booksellers ... in England, Scotland and Ireland from $I 668$ to $I 725$ and A Dictionary of the Printers and Booksellers ... in England, Scotland and Ireland from 1726 to 1775 , by Henry R. Plomer, G.H. Bushnell, and E.R. McC. Dix (both London: Oxford University Press, I922, 1932).

The list that follows contains fifty-one entries of religious periodicals published in England between I 660 and I 800 . Wherever possible, an attempt has been made to note (I) the full title of the periodical; (2) the publisher, printer, or editor; (3) the inclusive dates during which the news-sheet or journal was published; (4) the number of issues or volume; (5) the place of publication. The entries are arranged alphabetically, by title.

The Arminian Magazine. London: John Atlay, January I778-I797. 20 vols. Edited by John Wesley (I703-179I) and George Story (d. I818). The Aurora; or, the Dawn of Genuine Truth. London, I799-1 800. Published by The New Church (Swedenborgian).

The Balm of Gilead. London, 4 January I7 I4-5 February I7 I4.

The British Critic, a New Review. London, I793-1813. Edited by William Beloe and Robert Nares.

Catholic Intelligence: or, Infallible News both Domestic and Foreign. London: Printed for John Howe in Sweeting's Alley, Cornhill, I March 1680-29 March I680. Five numbers. A satirical news-sheet in the Protestant interest.

The Christian Miscellany; or, Religious and Moral Magazine. London, I792. Eight numbers.

The Christian Priest. London, 3 June $1720-10$ June 1720 . Three numbers. The Christian's Magazine. London, I 760-I 767 . Eight vols. Edited by William Dodd (1729-I 777). This journal continually assailed Wesley's doctrine of Christian Perfection.

The Christian's Magazine; or, Gospel Repository. London, I790-I 792. Three vols. Edited by Thomas Priestley.

Church-Man. London, 29 October I 7 I 8 . Only copy recorded.

The Evangelical Magazine. London, 1793-I 812. 20 vols.

The General Baptist Magazine. London, I 798-180o. Edited by D. Taylor.

The Gospel Magazine and Theological Review. London, I 796-I 805.

The Gospel Magazine; or, Spiritual Library, Designed to Promote Religion. London, I $766-1773$.

The Gospel Magazine, or Treasury of Divine Knowledge. London, I7741784. Edited by Augustus Montague Toplady (1740-I778). Toplady's hymn, "Rock of ages, cleft for me," appeared (in part) first in the October I 775 number (p. 474), and then the complete text followed in the number for March 1776 . 
The Impartial Protestant Mercury, or Occurrences, Foreign and Domestick. London: Printed for H.V. and T.C. Published and are to be Sold by Richard Janeway [Senior] in Queen's Head Alley in Pater-Noster Row, 7 May I68I-30 May I682. I I5 numbers. Primarily a means whereby Janeway carried on his quarrels with other publishers of Protestant newssheets.

The Jesuite. London, I5 August I719-3 October I719. Nine numbers.

The Jesuit. London, I 783 . Two numbers.

The Library; or, Moral and Critical Magazine. London, 1761-1762.

The London and Country Journal. With the History of the Old and New Testament. London, 6 June I739-4 February 1742. 142 numbers.

The Loyal Protestant and True Domestick Intelligence; or, News both from City and Country. Published to Prevent the Many False, Scandalous and Seditious Reports. London: Printed by Nathaniel Thompson [printer for the Noncomformists and Roman Catholics], Next the Cross Keys in Fetter Lane, 9 March I68I-20 March I683. 247 numbers.

Memoirs for the Curious; or, an Account of What Occurs That's Rare, Secret, Extraordinary, Prodigious and Miraculous through the World, Whether in Nature, Art, Learning, Policy, or Religion. London: Printed by Richard Janeway [the younger] for Ann Baldwin, I701. Two numbers. Illustrated.

Mercurius Theologicus; or, the Monthly Instructor. Briefy Explaining and Applying All the Doctrines and Duties of Christian Religion That Are Necessary To Be Believ'd and Practis'd in Order to Salvation. By a Divine of the Church of England. Printed by R.C. for John Taylor [bookseller], I 700-I 70I. Twelve numbers.

The Methodist Magazine. London, 1798-1821. Edited by George Story (d. 1818) and Joseph Benson. 24 vols. The direct successor to The Arminian Magazine; in fact, the former comprises volumes $2 \mathrm{I}-44$ of the latter.

A Monthly Intelligence Relating to the Affaires of the People Called Quakers. London, August-September I662. One number only.

The New Spiritual Magazine; or, Evangelical Treasury of Experimental Religion. London, $1783-1785$.

The Observator Observ'd; or Protestant Observations upon Anti-Protestant Pamphlets. By Way of Question and Answer. London: Printed for T. Davies [bookseller], Friday, 6 May I68I ; Printed for J. Gilford, May I68I. Three numbers. A reaction against The Observator. In Question and Answer. London: Printed for Henry Brome [d. 168I] at the Gun in St. Paul's Churchyard, I3 April I68I-9 March 1687. Edited by Sir Roger L'Estrange (1616-1704), The Observator attacked Whigs, Titus Oates, and Dissenters.

The Occasional Paper upon the Subject of Religion and the Church Establishment. London, 1735-1 736. Ten numbers.

The Old Whig; or, the Consistent Protestant. London, I 735-I 739. 
The Patriot, or Political, Moral and Philosophical Repository. London, I792I 793 .

The Protestant Advocate. With Remarks upon Popery, Serious and Comical. London, 1724.

The Protestant Dissenter's Magazine. London, I 794-I 799.

The Protestant Mercury. Occurrences, Foreign and Domestick. London:

Printed by Ichabod Dawks [1673-1730] in Ward-robe Court in Great Charter Lane near the West End of St. Paul's, 5-7 January 1697-25-30 March 1698.

The Protestant Mercury; or, the Exeter Post-Boy. Exeter: Printed by Joseph Bliss, at His New Printing-House near the London Inn, without EastGate, 17 15. The only evidence of this periodical is a reproduction of the title page of the fourth number ( 7 October 1715) in the Transactions of the Devonshire Association, 20 (1868), I 70.

The Protestant Observator; or, Democritus Flens. London, I681. Ten numbers.

The Protestant $O x$ ford Intelligence; or, Occurrences Foreign and Domestick. London: Printed for Thomas Benskin, in St. Bride's Churchyard, Io March I68I-3I March I68I. Seven numbers. Continued as the Impartial London Intelligence (four numbers: 4 April I68I-I4 April I68I). Benskin was a publisher on the Protestant side during the Popish Plot of $168 \mathrm{I}$.

The Protestant Packet; or, British Monitor. Newcastle-upon-Tyne, I $780-$ $178 \mathrm{I}$.

The Protestant Post-Boy. London: Printed and Sold by Sarah Popping, also by B. Harris, I 5-I 7 November I 7 I I-I-4 December I 7 I I.

Protestant York Courant. York, I 749. York Public Library houses numbers 224, 259, 266.

The Scourge. In Vindication of the Church of England. London, 4 February I 7 1 7-5 November I 7 7. Forty-three numbers.

Smith's Protestant Intelligence, Domestick and Foreign. Published for the Information of All True Englishmen. London: Printed for Francis Smith [bookseller] at the Elephant and Castle, near the Royal Exchange, in Cornhill, I February I68I-I4 April I68I. Twenty-two numbers. A news-sheet containing very little foreign news and only occasional inserted advertisements.

The Theological Miscellany and Review of Books on Religious Subjects. London, I 784-1 789. Edited by the Rev. C. DeCoetlogon.

The Theological Repository. London, I 766-1 770. Edited by Joseph Priestley (1733-1804).

The True Protestant (Domestick) Intelligence: or, News both from City and Country. Published to Prevent False Reports. London, Friday 23 April 1680-I4 May 1680. Seven numbers.

The True Protestant Mercury; or, an Impartial Historv of the Times. Lon- 
don: Printed for Richard Janeway [senior], 6 December 1689. One number.

The True Protestant Mercury; or, Occurrences Foreign and Domestick. London: Printed for H. Vile and T. Vile. Sold by Langley Curtiss on Ludgate Hill, Tuesday, 28 December I680-I 8 October I682. I 86 numbers.

The Universalists' Miscellany; or, Philanthropist's Museum. Intended Chiefty As an Antidote against the Antichristian Doctrine of Endless Misery. London, I797-1801. Edited by William Vidler.

The Weekly History; or, an Account of the Most Remarkable Passages Relating to the Present Progress of the Gospel. London: Printed by John Lewis, I I April I74I-I3 November 1742. Eighty-four numbers. The first Methodist newspaper, founded by those who seceded from John Wesley's societies: John Cennick, Howell Harris, Joseph Humphreys. A small folio of four pages.

The Weekly Mercury; or, Protestant's Packet. Norwich: Printed by William Chase, Cockney Lane, I $721-1723$.

The Weekly Remembrancer, Shewing the Best Way to Thrive and to Provide for the Poor. In a Dialogue between a Churchman and a Mystic. London: Printed for Oliver Hill, I 702-I 703 .

The Weekly Visions of the Late Popish Plot. London: Printed for Thomas Benskin in St. Bride's Church Yard, 168r. Seven numbers.

Zion's Triumph. Bristol, 1798-1801. Four vols. 